\title{
Electrocardiograms, high-dose antipsychotic treatment and College guidelines
}

\author{
Christopher Krasucki and Fran McFarlane
}

\begin{abstract}
A cross-sectional survoy of all in-patients at a poychiatiric hospltal was pertormed to see to what extent College guidelines on neuroleptic prescribing were being acthered to. Thirteen (7.3\%) patients were found to be on high doeses and one (0.6\%) on megadoses. Only $23 \%$ in the high-dose group had had on ECG at all, and just 7.7\% had hod one in the provious three months. The single patient on megadose treatment had had on ECG but not in the provious three months. Prescribing hablts that could potentially have lod to $21.9 \%$ of patients recelving high doses and $9.0 \%$ megadoeses were ldentilied, and reasons for the low rate of ECEs discussed.
\end{abstract}

In April 1994, the Royal College of Psychiatrists issued a Consensus Statement on the use of highdose antipsychotic medication (Thompson, 1994). This followed concern in recent years that "a number of deaths may be occurring in psychiatric patients which might be the result of the medication received rather than the severe illnesses from which most patients suffer". There had also been unease that some patients were being treated with doses of antipsychotic medication which were above, and sometimes markedly above, the recommended guidelines for dose schedules in the Brttish National Formulary (BNF, Royal Pharmaceutical Society, 1994; Thompson, 1994).

Although clinical experience suggests that the antipsychotic group of drugs generally has a good margin of safety, case reports dating back to 1960 have implicated phenothiazines, butyrophenones and other antipsychotic agents in the sudden death of patients. While current epidemiological evidence does not allow a claim for causality to be made, there does appear to be a plausible link mediated by the action of antipsychotics on the heart (McGrath et al, 1987).

Thioridazine, chlorpromazine, other antipsychotics and tricyclic antidepressants have a variety of cardiac effects including prolongation of cardiac conduction, which can manifest itself on the electrocardiogram (ECG) as a lengthened gT interval. When corrected for heart rate using a simple formula, a figure for the corrected GT interval (QTc) emerges, which can be compared with the normal range for this measure. Long $Q T$ intervals have been found in patients on ant1psychotics shortly before the onset of fatal ventricular arrhythmia, and are also found in rare, naturally occurring syndromes where cardiac arrhythmias are induced by exercise or emotion and lead to sudden death in childhood or early adulthood.

The College guidelines suggest that, for patients being started on antipsychotics at doses above the recommended upper limit, an ECG is carried out beforehand to exclude long QT syndromes, and then repeated every one to three months while the dose remains high. If a prolonged $\mathrm{gT}$ interval develops, a reduction of dose is recommended.

The aim of this study was to assess, five months after the publication of the Consensus Statement. how many patients on high-dose or megadose antipsychotic medication had had ECGs in accordance with its guidelines.

\section{The study}

The study was carried out in August 1994 at the Bethlem Royal Hospital, a large psychiatric unit in south London with both acute admission and rehabilitation faclities. Also on site are learning difficulties, drug dependence, eating disorders, forensic, behaviour therapy, mother and baby, and children's in-patient facilities.

Six weeks beforehand, all consultants and ward managers were informed by letter of our wish to carry out a survey of prescribing habits, and asked to make the prescription charts and medical notes of all patients on that ward available on a particular named day. Consent was obtained from all wards.

On the study day, two researchers (CK and FM) visited all wards in the hospital and looked at the current prescription charts and medical notes of every in-patient. Data was collected on an item sheet and included: age; gender; all antipsychotic medication (regular and prn) prescribed for the preceding day: whether there was an ECG in the 
Table 1. Chlorpromazine dose equivalent conversion figures

\begin{tabular}{|c|c|c|c|}
\hline Drug & $\begin{array}{l}\text { Equivalent does } \\
\text { (Consensus) (mg) }\end{array}$ & $\begin{array}{l}\text { Equivalent dose } \\
\text { (luncbeck) (mg) }\end{array}$ & $\begin{array}{l}\text { Range of values in } \\
\text { iferature (ma) }\end{array}$ \\
\hline $\begin{array}{l}\text { Chlorpromazine } \\
\text { Thloridozine } \\
\text { Fluphenazine } \\
\text { Trifluoperazine } \\
\text { Flupenthixol } \\
\text { Zuclopenthixol } \\
\text { Haloperidd } \\
\text { Droperidd } \\
\text { Sulpiride } \\
\text { Pimozide } \\
\text { Loxapine } \\
\text { Clozapine } \\
\text { Risperidone } \\
\text { Fluphenczine depot } \\
\text { Plpothiczine depot } \\
\text { Haloperidd depot } \\
\text { Flupenthixol depot } \\
\text { Zuclopenthlxol depot }\end{array}$ & $\begin{array}{l}100 \\
100 \\
2 \\
5 \\
3 \\
25 \\
3 \\
4 \\
200 \\
2 \\
10 \\
50 \\
2 \\
5 / \text { week } \\
10 / \text { weok } \\
15 / \text { week } \\
10 / \text { weok } \\
100 / \text { week }\end{array}$ & $\begin{array}{l}100 \\
100 \\
- \\
- \\
- \\
- \\
5 \\
- \\
- \\
- \\
- \\
- \\
\overline{1} \\
- \\
\overline{-} \\
20 / \text { werk } \\
100 / \text { werk }\end{array}$ & $\begin{array}{l}- \\
75-100 \\
2-5 \\
2.5-5 \\
2-3 \\
25-60 \\
1.5-5 \\
1-4 \\
200-270 \\
2 \\
10-25 \\
50-90 \\
? \\
1-12.5 / \text { week } \\
10-12.5 / \text { weok } \\
5-25 / \text { werk } \\
10-20 / \text { weok } \\
40-100 \text { /weok }\end{array}$ \\
\hline
\end{tabular}

notes; whether an ECG had been done within the previous 1-3 months; and the QTC interval.

Using this data, the total chlorpromazine dose equivalent for the prescribed medication was calculated according to established conversion figures (Taylor et al, 1994; Table 1), looking both at what was actually administered ('actual chlorpromazine dose equivalent') and what might have been given within the confines of the prescription chart ('potential chlorpromazine dose equivalent'). A 'high dose' was defined as over the accepted BNF upper dose limit for monotherapy, or over $1000 \mathrm{mg}$ of chlorpromazine equivalent if two or more drugs were being prescribed, and a 'megadose' as over $2000 \mathrm{mg}$ of chlorpromazine equivalent. QTe was calculated using the formula: $Q T c=Q T /$ square root $R R$ interval. A QTC interval of $\mathbf{4 4 0}$ milliseconds or greater was considered 'lengthened'. The Statistical Package for Social Sciences (SPSS) for Windows, Version 6.0, was used for data analysis.

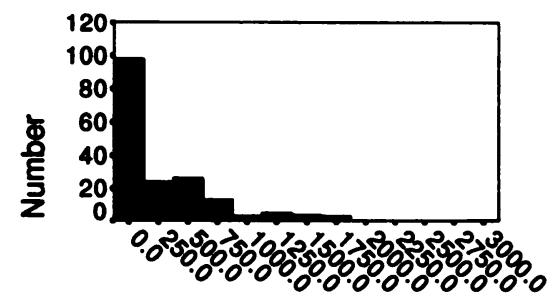

Actual chlorpromazine dose equivalent

Figure 1. Actual chlorpromazine dose equivalents (s.d.=458.63; mean=297.3; $n=177$ )

\section{Findings}

Notes and prescription charts were obtained for $177(99.4 \%)$ of the 178 patients in hospital on the day of the study. Of these, $109(61.6 \%)$ were male and $68(38.4 \%)$ female. Their ages ranged from 13 to 63 (mean=31.9; s.d.=11.33). Age data were missing for three of the 178 original subjects. One prescription chart was missing, but for the remainder the range in chlorpromazine dose equivalent was 0 to $2900 \mathrm{mg}$, with a mean of $297 \mathrm{mg}$ (s.d.=459 mg). Chlorpromazine dose equivalents are displayed in Figure 1. Ninetytwo (52\%) of the 177 patients with prescription charts available were receiving neuroleptic medication; 13 (7.3\%) were being given a chlorpromazine equitvalent dose of above $1000 \mathrm{mg}$, and of these, one $(0.6 \%)$ was recetving an equivalent dose of over $2000 \mathrm{mg}$ of chlorpromazine.

When what was potentially prescribable was considered, however, 39 (21.9\%) of the 177 patients fell into the high-dose category, of whom $16(9.0 \%)$ could potentially be given a megadose (Table 2). For two subjects, the notes were unavailable and so could not be checked to ascertain whether an ECG had been done. An ECG was found in 11 (6.3\%) of the remaining 176 sets of notes, and two (1.1\%) sets of notes contained an ECG that had been performed in the previous three months. Whereas the single patient who was on megadose treatment had an ECG in his notes $(100 \%)$, only three (23\%) out of the 13 patients on high-dose treatment had one.

When the College's criteria of having had an ECG within the previous three months were applied, it emerged that the patient on megadose 
ORIGINAL PAPERS

Table 2. Prescription charts

\begin{tabular}{lc}
\hline & Number (\%) \\
\hline Total in-patient population & 178 \\
Prescription charts avallable & $177(100)$ \\
Male patients & $109(61.6)$ \\
Female patients & $68(38.4)$ \\
Recelving neuroleptic medication & $92(52)$ \\
Recelling high doses & $13(7.3)$ \\
Recelving megadoses & $1(0.6)$ \\
Potential high doses & $39(21.9)$ \\
Potential megadoses & $16(9.0)$ \\
Medical notes avallable & $176(100)$ \\
ECG in the notes & $11(6.3)$ \\
ECG in the last three months & $2(1.1)$ \\
\hline
\end{tabular}

treatment did not have one (0\%), and only one (7.7\%) out of the 13 in the high dose group had.

When potential high doses and megadoses were considered, five (12.8\%) out of the 39 patients on potential high doses had an ECG in their notes, and one (2.6\%) out of the 39 had had one in the previous three months. With regard to potential megadoses, two (12.5\%) out of the 16 in this group had an ECG in their notes, and one (6.3\%) of the 16 had had one in the previous three months (Table 3).

Altogether, 10 of the 11 ECGs in the notes were sufficiently legible to allow measurement of the QT interval. Of the ten, five (50\%) showed a lengthened corrected QT interval, and one (20\%) of the five was in the group receiving high dose medication. The association between lengthening of the corrected QT interval and high dose treatment was not found to be statistically significant in this small sample (Fisher's exact test, two-tail, d.f.=1, $P=1.00$ ).

\section{Comment}

While in this mixed sample of psychiatric patients the rate of high-dose and megadose neuroleptic

Table 3. Avallability of ECG notes

\begin{tabular}{lccl}
\hline & $\begin{array}{l}\text { Tolat } \\
\text { number } \\
(\%)\end{array}$ & $\begin{array}{l}\text { ECG in } \\
\text { notes } \\
(\%)\end{array}$ & $\begin{array}{l}\text { ECG in last } \\
\text { three } \\
\text { months } \\
(\%)\end{array}$ \\
\hline $\begin{array}{l}\text { Recelving neuro- } \\
\text { leptic medication } 92(100)\end{array}$ & $\begin{array}{c}10(10.9) \\
3(23)\end{array}$ & $\begin{array}{l}2(2.2) \\
1(7.7)\end{array}$ \\
$\begin{array}{l}\text { High-dose patients } 13(100) \\
\text { Megadose patients } 1(100)\end{array}$ & $1(100)$ & $0(0.0)$ \\
$\begin{array}{l}\text { Potential high-dose } \\
\text { patients }\end{array} 39(100)$ & $5(12.8)$ & $1(2.6)$ \\
$\begin{array}{l}\text { Potentlal megadose } \\
\text { pattents }\end{array} 16(100)$ & $2(12.5)$ & $1(6.3)$ \\
\hline
\end{tabular}

treatment was relattvely low, it is nevertheless worrying that less than a quarter of this group had had an ECG at all and less than $10 \%$ had had one within the previous three months as recommended in the Royal College of Psychiatrists' Consensus Statement. Although the indication for ECGs was not recorded, the fact that as an investigation they are also requested for screening prior to the use of a tricyclic antidepressant. lithium or electroconvulstve therapy, and in the investigation of cardiovascular symptoms, suggests the possiblity that even this small number is an overestimate of the true number requested with high-dose and megadose neuroleptic prescribing in mind.

Also of concern is the fact that when what is potentially administrable is considered, the number of patients who could recetve medication above $B N F$ guidelines is trebled, and the number who could be treated with megadoses is increased 15-fold. Some patients are likely to have been written up for these potentially large neuroleptic doses inadvertently, as chlorpromazine dose equivalent totals take time to calculate and require conversion data, while others are likely to have been written prescription charts in the expectation that nursing and medical staff would make decisions about the safety or otherwise of amounts prescribed if and when they were needed. Patients in these two groups are much less likely to have had an ECG, and so there is a sizable risk that if large amounts of 'as required' medication were needed, they would be administered rapidly and at above BNF guidelines to a patient in whom electrocardiographic abnormality had not been excluded. There would be no baseline ECG to compare with if cardiac complications ensued.

Much has been written about sudden deaths in psychiatric patients on neuroleptic treatment and the possible link with electrocardiographic abnormalities. Most of such studies have been retrospective, and authors have repeatedly emphasised the potential value of looking at this important area in a prospective fashion. In this study, only about $10 \%$ of such patients had had an ECG, making it difficult not only to look for associations between prescribing habits and electrocardiographic abnormalities, but also to institute any kind of prospective approach to monitoring neuroleptic prescribing safety.

ECGs are often not done because it is not obvious at admission that a particular patient will need high-dose neuroleptic treatment. On the other hand, some of the doctors we spoke to were aware their patients were on high doses and needed an ECG but had simply had not yet had time to get the apparatus to the ward and do it. In some cases, an ECG had been done, but because it was in the form of a 'ticker tape' strip, it had become detached from the notes and been lost. 
Table 4. Draft recommended guidelines and when ECG should be performed

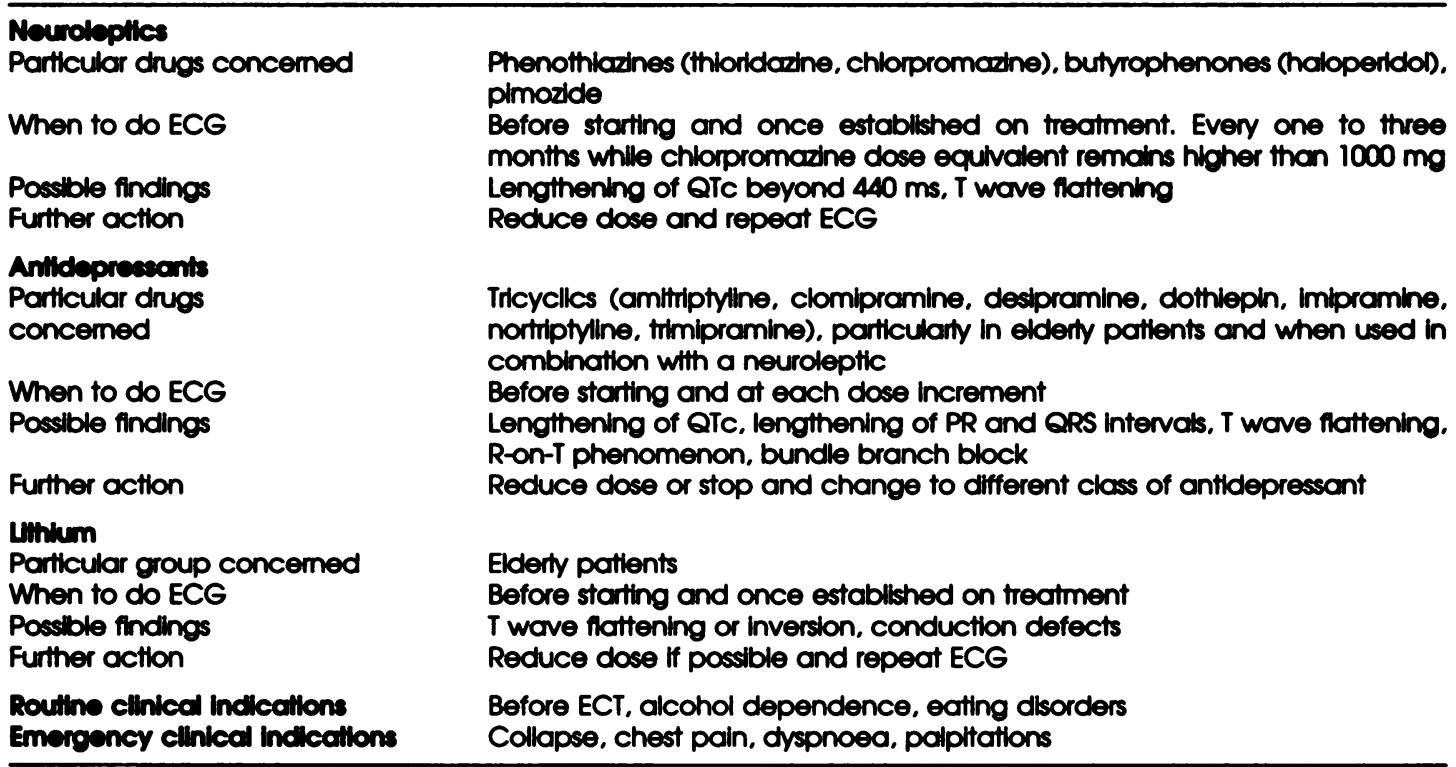

One 'ticker tape' ECG had faded to the extent that it was illegible.

It is unlikely that the need to prescribe neuroleptic medication at above BNF guidelines in a significant minority of psychiatric patients will disappear in the immediate future. Prescribers should, however, have access to a means of calculating when the combination of regular and 'as required' neuroleptics they are giving a patient constitutes a real or potential high dose, and then be able to obtain an ECG, preferably of A4 size, which can be safely stowed away in the medical notes.

At the Bethlem Royal and Maudsley Hospitals, the following changes are consequently being implemented:

- A new ECG machine is being purchased for each site. The machines will be able to automatically measure the $\mathrm{gT}$ and QTC intervals and print them out with the ECG itself on A4 size paper. Arrangements are also being made with the cardiology department of another hospital to provide an ECG reporting service. In cases of doubt as to whether an ECG is abnormal, or what the significance of a particular ECG finding may be, the ECG will either be copied and posted or faxed to the cardiologists for an opinion. It is hoped that this service will be able to operate on a 24 hour basis.

- The pharmacy departments at the hospitals have begun to routinely and regularly calculate total chlorpromazine dose equiva- lents for each prescription chart and record them on the chart in order to assist staff in prescribing at levels below the high and megadose ranges and allow early identification of patients who have entered those ranges.

- Recommended guidelines for when an ECG should be performed are being drawn up. It is anticipated that, in addition to satisfying the College guidelines on high-dose prescribing, they will raise awareness of the potential problem of cardiotoxity in other psychotropic drugs and lead to both safer prescribing and better monitoring of patients receiving such treatment. The first draft on the guidelines is shown in Table 4.

- A larger, prospective study of ECG changes in patients recetving psychotropic medication is planned and will take advantage of the improved monitoring and reporting services.

Perhaps we are moving towards the day when an ECG becomes part of the routine work-up of all psychiatric patients requiring pharmacotherapy.

\section{References}

MCGRATH. P. J., BLOOD, D. K. STEWART, J. W.. et al (1987) A comparattve study of the electrocardiographic effects of phenelzine. tricyclic antidepressants, miansertn, and placebo. Joumal of Clinical Psychopharmacology. 7. 335-339. 
Royal Pharmaceutical Society of Great Brtann (1994) Brttish National Formulary. Bath: Bath Press.

TAYLor, D., Duncan, D. \& HeuwEL, M. (1994) Neuroleptic dose equitralencies. Bethlem and Maudsley Trust Pharmacy Department Drug Information Quarterty, $\mathbf{3}$. ThOMPSON, C. (1994) The use of high-dose antipsychotic medication. Consensus Statement. British Journal of Psychiatry, 164, 448-458.
"Christopher Krasuckd, Registrar, Maudsley Hospital, Denmark Hill, London SE5 8AZ; and Fran McFarlane, Pharmacist, Bethlem Royal Hospital

"Correspondence

Edited by David J. King
Psychopharmacology is a key both to the understanding of the biological

